\title{
Analysis of the Intercaste Transcriptional Profile of Melipona scutellaris Latreille, 1811 (Hymenoptera, Apidae, Meliponini) by mRNA Differential Display
}

\author{
ANA CAROLINA S. SIQUIEROLI ${ }^{1}$; CARLOS U. VIEIRA ${ }^{1}$; GISLENE A. CARVALHO- \\ ZILSE$^{2}$; LUIZ R. GOULART ${ }^{1}$; WARWICK E. KERR ${ }^{1}$ and ANA M. BONETTI ${ }^{1}$ \\ ${ }^{1}$ Institute of Genetics and Biochemistry (INGEB), Federal University of Uberlândia, Umuarama, Bloco 2E, \\ Sala 24. CEP: 38400-902. Uberlândia, MG, Brazil. \\ ${ }^{2}$ National Institute of Amazon Research (INPA) / Bee Research Group (GPA), 69060-040, Manaus, AM, \\ Brazil.
}

\begin{abstract}
In colonies of Melipona scutellaris Latreille, 1811 workers can be found with four ganglion nerve cells, a morphological characteristic of the queen. It is hypothesized that these workers, called intercastes, or phenocopies, are phenotypically-like workers, but genotypically identical to queens due to this specific trait. Workers with the same number of ganglion as queens seem to be intercastes between queens and workers. Our objective was to analyze the mRNA profiles of workers, queens, and intercastes of $M$. scutellaris through DDRT-PCR. Three hundred (300) pupae with white eyes were collected and externally identified according to the number of abdominal nerve ganglions: workers (5 ganglions), queens (4 ganglions) and intercastes (4 ganglions). The analysis identified differentially expressed transcripts that were present only in workers, but absent in intercastes and queens, confirming the hypothesis, by demonstrating the environmental effect on the queen genotype that generated phenotype-like workers.
\end{abstract}

Key terms: determination of castes, intercastes, Melipona sp.

Corbiculates social bees constitute the Apidae family among which stingless Brazilian bees (Melipona sp) stand out for their essential importance to different Brazilian ecosystems, especially for pollination (Imperatriz-Fonseca et al., 2006), dispersion of seeds (Bacelar-Lima et al., 2006), and furthermore, for their importance in food, popular medicine and family incomes, because of the quality and acceptance of its honey and pollen (Kerr et al., 2001)

For centuries these bees have been cultivated all over the country, especially in the North and Northeast that are the birthplace of the first two domestic species: Melipona compressipes fasciculata and Melipona scutellaris (Kerr et al., 1996). The latter popularly known as "uruçu" of the Northeast is one the best known species biologically, especially due to its peculiar mechanism of determination of castes, as a consequence of its genetic-feeding interaction, which is different from the pattern presented by other Apidae. It is found from Bahia to Rio Grande do Norte, mainly in "Zona da Mata" (Forest Zone) (Carvalho, 2001).

Bee castes are characterized by morphology, physiology and behavior of females who live together in a beehive (Michener, 1974). Kerr (1974) suggested that the genetic-feeding control in the determination of castes for Melipona bees is not totally regulated by differential feed of larva, but also by two genes $\mathrm{Xa}$ and $\mathrm{Xb}$. These genes acting together in the prepupal stage influenced by a sufficient amount of

\footnotetext{
* Corresponding author: Institute of Genetics and Biochemistry (INGEB), Federal University of Uberlândia, Umuarama, Bloco 2E, Sala 24. CEP: 38400-902. Uberlândia, MG, Brazil. carolsiquieroli@yahoo.com.br
} 
food ingested by the larval stage individual could lead to the development of a worker when in simple or double homozygosis. Double heterozygosis $\left(\mathrm{Xa}^{1} \mathrm{Xa}^{2} ; \mathrm{Xb}^{1} \mathrm{Xb}^{2}\right)$ can lead to queen differentiation, as long as the larva receives sufficient food, in a ratio of up to $25 \%$ (Bonetti, 1982).

One of the hormones involved in the process of the insects' metamorphosis is the Juvenile Hormone ( $\mathrm{JH})$, synthesized by the endocrine glands corpora allata (CA) and secreted in hemolymph, which somehow promotes the interaction of the CA with the genome, probably via the nuclear receptor of the superfamily of steroids (Davey, 2000). The JH functions as an inducer of several genes responsible for the phenotype of a complete female (queen) (Bonetti, 1982), and acts in the final larval stage (Mateus et al., 2002).

In the pupal stage of white eyes $M$. quadrifasciata and $M$. marginata, the abdominal nerve cord presents 5 (five) nerve ganglions in workers and 4 (four) in queens. In the colony there may be occurrences of workers with 4 (four) nerve ganglions, which are considered phenotypically like workers, but genotypically identical to queens (Kerr and Nielsen, 1966). This happens in a similar manner with workers of $M$. scutellaris with the same number of queen ganglions suggesting that the latter are intercastes between queens and workers, if feeding is absent or not enough to produce the necessary $\mathrm{JH}$ to activate determinant caste genes. These intermediate cast individuals behave as normal workers participating in the various stages in the construction and provisioning of brood cells, as has also been observed by Mateus et al. (2002) in $M$. seminigra and Capas and Souza (1992) in M. quadrifasciata.

The many different cell types in animals allow organs and tissues to play distinct physiological roles. The genetic material of an individual is equal in all of its cells, but the expression pattern is different in each cellular type. Effective methods are necessary to identify the differential expression of genes in different tissues or under specific conditions, as is the case of the DDRT-PCR technique (Differential
Display Reverse Transcriptase - Polymerase Chain Reaction) (Liang and Pardee, 1992) which uses the properties of PCR to obtain cDNA from the total RNA of an eukaryote, by using a poli-T primer that anneals to the poli-A mRNA tail.

Vieira et al. (2006) have identified by DDRT-PCR technique the differential expression of genes in M. scutellaris after topical application of JH III in larvae, demonstrating the efficacy of this technique to evaluate transcriptional profiles in this species.

Therefore, the aim of this study was to identify the differential expression of genes in pupae of white eyed workers, queens and intercastes of $M$. scutellaris by DDRTPCR.

Three hundred (300) pupae with white eyes of $M$. scutellaris (queens, workers and intercastes) were collected of beehives from

\section{B $\quad$ W IN $\quad$ Q}

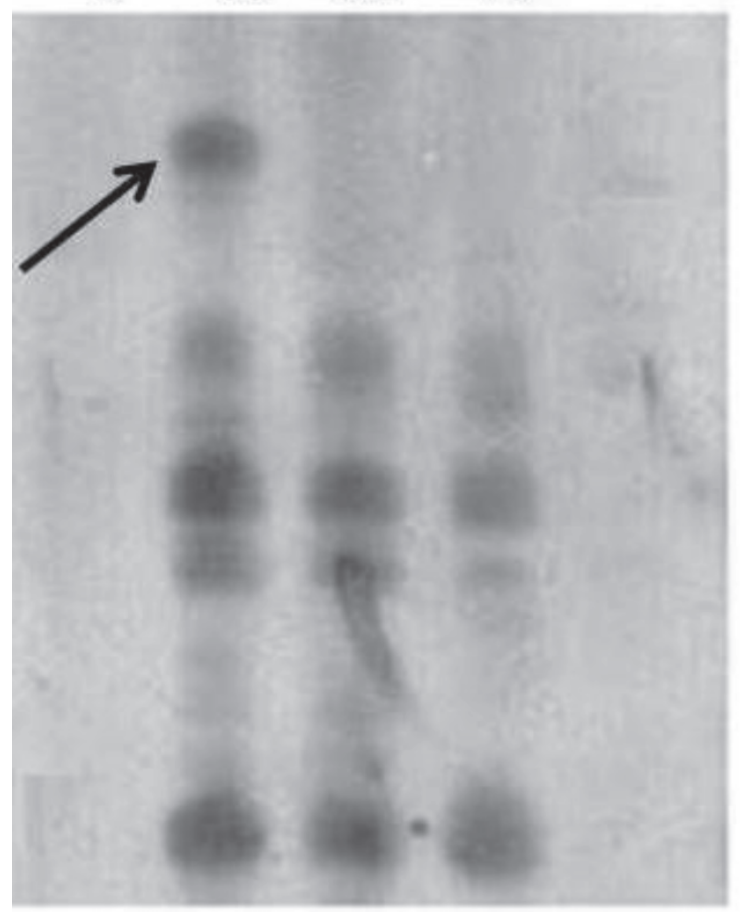

Figure 1: DDRT products (HT11G-AP5 primer combination) in gel of polyacrylamide $6 \%$, urea $8 \mathrm{M}$, at $120 \mathrm{~V}$ for $18 \mathrm{~h}$ stained with silver nitrate. B: negative controls (without RNA). W: workers. IN: intercastes. Q: queens. The arrow indicates differential expression. 
the coast of Bahia (Catu - S 12० 21'; WGR $38^{\circ} 23^{\prime}$ ) and the Chapada Diamantina (Lençóis - S $12^{\circ} 34^{\prime}$; W-GR 41 ${ }^{\circ} 23$ '; Piatã - S $13^{\circ} 8^{\prime} ; \mathrm{W}-\mathrm{GR} 41^{\circ} 46^{\prime}$ and Andaraí - S $11^{\circ} 41^{\prime}$; W-GR $40^{\circ} 38^{\prime}$ ') in period between August and September and maintained in the Uberlândia Meliponary (UberlândiaMG - S $18^{\circ} 55^{\prime}$; W-GR $\left.48^{\circ} 17^{\prime}\right)$. After that these maintained pupae were collected in the breeding honeycombs in meliponary beehives and preserved in an ultrafreezer $80^{\circ} \mathrm{C}$ until the experimental manipulation (Genetics and Biochemistry Laboratory, INGEB, UFU).

The pupae previously identified as workers or queens based on external morphology were dissected in Ringer Solution $\left(\mathrm{NaCl} 6,5 \mathrm{~g} ; \mathrm{KCl} 0,25 \mathrm{~g} ; \mathrm{NaHCO}_{3}\right.$ $0,20 \mathrm{~g} ; \mathrm{CaCl}_{2} 0,30 \mathrm{~g}$ ) to obtain the number of nerve ganglions that constitutes abdominal nerve cord. The differentiation was made between workers (with 5 ganglions), queens (4 ganglions) and intercastes (workers with 4 ganglions). The remaining material was used for extraction of RNA and the intestine was removed to avoid contamination.

For analysis of the gene expression, pools of 10 individuals from each group (queens, workers and intercastes) were used. The RNA extraction was done using the protocol described by Trizol (GIBCO). After that, the material was treated with DNase I and qualified by $1 \%$ agarose electrophoresis gel stained with ethidium bromide. The total RNA was quantified by spectrophotometer (Ultrospec 1000 Pharmacia Biotech) at $260 \mathrm{~nm}$ and the RNA average was $300 \mathrm{mg}$ for each pool $(n=10$ bees for each group).

The reverse transcription (RT) reaction was carried out at $37^{\circ} \mathrm{C}$ for 1 hour using $200 \mathrm{ng}$ of total RNA, 8 pmols of the anchored oligo-dT primers (Table 1) and 200 U of RTII Superscript II (GIBCO). A reaction without RNA was done for a general negative control. The reverse transcriptase enzyme was not added to the negative controls (sample blanks) in order to check contamination by DNA.

The PCR amplification reactions were carried out according to the following protocol: $1 \mu \mathrm{L}$ of the RT reaction, Taq $1 \mathrm{X}$ buffer, $2.5 \mathrm{mM}$ of magnesium chloride, 200 $\mu \mathrm{M}$ of dNTPs, $8 \mathrm{pmol}$ of oligo-DT primer, 8 pmol of arbitrary primer (Table 1 ) and 1 $\mathrm{U}$ of Taq DNA polymerase enzyme, in a final volume of $30 \mu \mathrm{L}$. The amplifications were done in a thermocycler set for 40 cycles at $94^{\circ} \mathrm{C}$ for $25 \mathrm{~s}, 40^{\circ} \mathrm{C}$ for $2 \mathrm{~min}$, and $72^{\circ} \mathrm{C}$ for $1 \mathrm{~min}$, followed by a final extension temperature $72^{\circ} \mathrm{C}$ for $5 \mathrm{~min}$.

TABLE 1

Sequence of the oligo-dT (HT11) and arbitrary primers (AP) used in the DDRT-PCR experiments

\begin{tabular}{lr}
\hline Primers & Sequence $5^{\prime} \rightarrow 3^{\prime}$ \\
\hline HT11A & AAGCTTTTTTTTTTTA \\
HT11C & AAGCTTTTTTTTTTTC \\
HT11G & AAGCTTTTTTTTTTTG \\
AP01 & AAGCTTGATTGCC \\
AP02 & AAGCTTGCACTGT \\
AP03 & AAGCTTTGCTCAG \\
AP04 & AAGCTTCTCAAGG \\
AP05 & AAGCTTAGTAGGC \\
\hline
\end{tabular}

An electrophoresis of the amplified products was processed in gel of polyacrylamide $6 \%$, urea $8 \mathrm{M}$, at $120 \mathrm{~V}$ for $18 \mathrm{~h}$. The visualization of the bands was obtained by silver nitrate staining according to Blum et al. (1987), with modifications by Basam et al. (1991).

Among the total collected bees (300 pupae) 231 workers and 69 queens were found, following segregation in a ratio of 3 workers for 1 queen, as proposed by Kerr and Nielsen (1966) and Kerr (1974). Only 10 (ten) individuals were found with characteristics of intercastes, indicating that the period was not propitious for their appearance in the colonies studied, which certainly depends on an adequate number of flowers to provide enough food for the development of queens in the heterozygous individuals.

After standardization, the combined primers HT11G /AP5 were selected to analyze differential expressions of genes among workers, intercastes and queens. The transcripts were expressed in the workers 
(with 5 ganglions), but not in intercastes and queens (both with 4 ganglions). Therefore, it is considered that queens and intercastes are genetically similar to these transcripts differing from workers.

These results, together with the number of ganglions encountered in the different individuals, corroborated with Kerr and Nielsen (1966) who suggest that individuals externally identified as workers, but presenting 4 (four) abdominal ganglions nerves, correspond genotypically to queens.

In conclusion, the intercastes presented a genotypical similarity to the queens and were differentiated from the workers in the transcriptional profile by mRNA differential display.

\section{ACKNOWLEDGEMENTS}

We are grateful to Angela A. S. Sena Priuli and Fausto Emíllio Capparelli for their comments. This work was supported by National Counsel of Technological and Scientific Development (CNPq) and the Federal University of Uberlândia (UFU).

\section{REFERENCES}

BACELAR-LIMA CG, FREIRE DCB, COLETTO-SILVA A; LARAY JPB, COSTA KB, VILAS BOAS HC, CARVALHO-ZILZE GA (2006) Melitocoria de Zygia racemosa (Ducke) Barneby \& J. W. Grimes por Melipona seminigra merrillae Cockerell, 1919 y Melipona compressipes manaosensis Schwarz, 1932. Acta Amazonica, 36 (3): 343-348

BASAN BJ, CAETANO-ANOLES G, GRESSHOFF PM (1991) Fast and sensitive silver staining of DNA in polyacrylamide gels. Anal. Biochem. 196: 80-83
BLUM H, BEIR H, GROSS HJ (1987) Improved silver staining of plant proteins, RNA and DNA in polyacrylamide gel. Electrophoresis 93-99

BONETTI, AM (1982) Ação do Hormônio Juvenil sobre a Expressão Gênica em Melipona scutellaris (Hymenoptera, Apidae, Meliponinae). 1982. $141 \mathrm{f}$. Dissertação (Mestrado) - Faculdade de Medicina de Ribeirão Preto, Ribeirão Preto

CAPAZ , SOUZA JP (1992) Os Meliponídeos em Portugal e na Europa. IN: Congresso Ibérico de Entomologia, 5.,Lisboa. Anais...Lisboa. pp: 53-68

CARVALHO GA (2001) The number of sex alleles (CSD) in a bee population and its practical importance (Hymenoptera: Apidae). Acta Amazonica, 10: 10-15

DAVEY KG (2000) The model of action of juvenile hormones: some questions we ought to ask. Insect Biochesm. Mol. Biol. 30: 663-669

IMPERATRIZ-FONSECA VL, DE JONG D, SARAIVA AM (2006) Bees as Pollinators in Brazil: assessing the status and suggesting the best practices. Holos Ed., Ribeirão Preto, 114p

KERR WE (1974) Sex determination in bees III. Caste Determination and Genect control in Melipona. Insectes Soc. 21 (4): 357-368

KERR WE, NIELSEN RA (1966) Evidences that genetically determined Melipona queens can become workers. Genectics. 54 (3): 859-866

KERR WE, CARVALHO GA, NASCIMENTO VA (1996) (org.) Abelha Uruçu: biologia, manejo e conservação. Belo Horizonte: Fundação Acangaú, 144 p

KERR WE, CARVALHO GA, SILVA AC, ASSIS MGP (2001) Aspectos pouco mencionados da biodiversidade amazônica. Parcerias Estratégicas,12: 20-41

LIANG P, PARDEE AB (1992) Differential display of eukaryotic messenger RNA by means of the polymerase chain reaction. Science, 257: 967-971

MATEUS S, HRNCIR M, FAUSTINO CD, ZUCCHI R (2002) Ocorrência de intercastes adultas em colônias de Melipona seminigra: Aspectos morfo-etológicos preliminares (Hymenoptera, Apidae, Meliponini). IN: Encontro Sobre Bees, 5.,Ribeirão Preto. Anais...Ribeirão Preto, pp: 211-216

MICHENER, CD (1974) The social behavior of the bees Harward University Press, Cambridge, 12: 404

VIEIRA CU, SANTANA FA, SIQUIEROLI ACS, SOUSA CS, OLIVEIRA RC, HOMSI-BRANDEBURGO, BONETTI AM (2006) Differential Gene Expression in Melipona scutellaris (Hymenoptera, Meliponini) Effect of Juvenile Hormone III. Biosci. J. 22: 133-138 